Article

\title{
Discovery of a Kojibiose Hydrolase by Analysis of Specificity-Determining Correlated Positions in Glycoside Hydrolase Family 65
}

\author{
Emma De Beul (D, Alana Jongbloet, Jorick Franceus (D) and Tom Desmet * (D) \\ Centre for Synthetic Biology (CSB), Department of Biotechnology, Ghent University, Coupure Links 653, \\ 9000 Ghent, Belgium; emma.debeul@ugent.be (E.D.B.); alana.jongbloet@gmail.com (A.J.); \\ jorick.franceus@ugent.be (J.F.) \\ * Correspondence: tom.desmet@ugent.be; Tel.: +32-9264-9920
}

check for

updates

Citation: De Beul, E.; Jongbloet, A.; Franceus, J.; Desmet, T. Discovery of a Kojibiose Hydrolase by Analysis of Specificity-Determining Correlated Positions in Glycoside Hydrolase Family 65. Molecules 2021, 26, 6321. https://doi.org/10.3390/ molecules26206321

Academic Editor: Stefan Janecek

Received: 14 September 2021

Accepted: 14 October 2021

Published: 19 October 2021

Publisher's Note: MDPI stays neutral with regard to jurisdictional claims in published maps and institutional affiliations.

Copyright: (c) 2021 by the authors. Licensee MDPI, Basel, Switzerland. This article is an open access article distributed under the terms and conditions of the Creative Commons Attribution (CC BY) license (https:// creativecommons.org/licenses/by/ $4.0 /)$.

\begin{abstract}
The Glycoside Hydrolase Family 65 (GH65) is an enzyme family of inverting $\alpha$-glucoside phosphorylases and hydrolases that currently contains 10 characterized enzyme specificities. However, its sequence diversity has never been studied in detail. Here, an in-silico analysis of correlated mutations was performed, revealing specificity-determining positions that facilitate annotation of the family's phylogenetic tree. By searching these positions for amino acid motifs that do not match those found in previously characterized enzymes from GH65, several clades that may harbor new functions could be identified. Three enzymes from across these regions were expressed in E. coli and their substrate profile was mapped. One of those enzymes, originating from the bacterium Mucilaginibacter mallensis, was found to hydrolyze kojibiose and $\alpha$-1,2-oligoglucans with high specificity. We propose kojibiose glucohydrolase as the systematic name and kojibiose hydrolase or kojibiase as the short name for this new enzyme. This work illustrates a convenient strategy for mapping the natural diversity of enzyme families and smartly mining the ever-growing number of available sequences in the quest for novel specificities.
\end{abstract}

Keywords: Glycoside Hydrolase Family 65; glycoside phosphorylases; glycoside hydrolases; correlated positions; CMA; specificity determinants; kojibiase; kojibiose glucohydrolase

\section{Introduction}

In the carbohydrate-active enzymes database (CAZy) [1], 10 enzyme specificities (Table 1) are grouped to form the Glycoside Hydrolase Family 65 (GH65), which is a member of clan GH-L. All members of this enzyme family break $\alpha$-glucosidic bonds through a single displacement mechanism that inverts the anomeric configuration (Figure 1), but they differ in the substrates they prefer [2]. Based on the nucleophile that is used in the breakdown reaction, two groups can be distinguished: glucoside hydrolases use water to hydrolyze the glucosidic bond, whereas glucoside phosphorylases employ inorganic phosphate, releasing glucose or $\beta$-glucose 1-phosphate ( $\beta$ Glc1P) as a reaction product, respectively [3]. GH65 enzymes are typically active on $\alpha$-glucobioses (trehalose, kojibiose, nigerose or maltose) or derivatives thereof (trehalose 6-phosphate, $\alpha-1,2-$ or $\alpha-1,3$-oligoglucans), but a few other natural substrates have also been identified (3-O- $\alpha$-glucosyl-L-rhamnose, $2-O-\alpha-$ glucosylglycerol or the $\alpha$-glucosyl-1,2- $\beta$-galactosyl decoration found on hydroxylysine residues of collagen) $[2,4-6]$. 
Table 1. Overview of all currently identified GH65 enzyme specificities and their annotated representatives. Gal: Dgalactose, Glc: D-glucose, Glc6P: D-glucose 6-phosphate, Hyl: 5-hydroxy-L-lysine, L-Rham: L-rhamnose, $\beta$ Glc1P: $\beta$-Dglucose 1-phosphate.

\begin{tabular}{|c|c|c|c|c|c|}
\hline EC & Enzyme & Abbreviation & Substrate & Product & $\begin{array}{c}\text { Organisms with Annotated } \\
\text { Representatives }\end{array}$ \\
\hline 2.4.1.8 & $\begin{array}{l}\text { Maltose } \\
\text { phosphorylase }\end{array}$ & MP & Glc $\alpha 1 \rightarrow 4$ Glc & $\beta$ Glc1P & $\begin{array}{c}\text { Levilactobacillus brevis [7] } \\
\text { Fructilactobacillus sanfranciscensis [8] } \\
\text { Bacillus sp. [9] } \\
\text { Paenibacillus sp. [10] } \\
\text { Lactobacillus acidophilus sp. [11] } \\
\text { Salisediminibacterium selenitireducens [12] } \\
\text { Enterococcus faecalis [13] }\end{array}$ \\
\hline 2.4.1.64 & $\begin{array}{c}\text { Trehalose } \\
\text { phosphorylase }\end{array}$ & $\mathrm{TP}$ & Glc $\alpha 1 \rightarrow 1 \alpha \mathrm{Glc}$ & $\beta$ Glc1P & $\begin{array}{c}\text { Thermoanaerobacter brockii [14] } \\
\text { Geobacillus stearothermophilus [15] } \\
\text { Caldanaerobacter subterraneus [16] } \\
\text { Salisediminibacterium selenitireducens [17] }\end{array}$ \\
\hline 2.4.1.216 & $\begin{array}{l}\text { Trehalose-6- } \\
\text { phosphate } \\
\text { phosphorylase }\end{array}$ & Т6РP & Glc $\alpha 1 \rightarrow 1 \alpha$ Glc6P & $\beta$ Glc1P & $\begin{array}{c}\text { Lactococcus lactis [18] } \\
\text { Ca. Kuenenia stuttgartiensis [19] }\end{array}$ \\
\hline 2.4.1.230 & $\begin{array}{c}\text { Kojibiose } \\
\text { phosphorylase }\end{array}$ & $\mathrm{KP}$ & $\begin{array}{c}\text { Glc } \alpha 1 \rightarrow 2 \mathrm{Glc} \\
\text { Glc } \alpha 1 \rightarrow(2 \mathrm{Glc} \alpha 1 \rightarrow)_{\mathrm{n}-2} 2 \mathrm{Glc}\end{array}$ & $\beta$ Glc1P & $\begin{array}{c}\text { Thermoanaerobacter brockii [20,21] } \\
\text { Caldicellulosiruptor saccharolyticus [22] } \\
\text { Nostoc sp. [19] } \\
\text { Pyrococcus sp. [23] } \\
\text { Escherichia coli [24] }\end{array}$ \\
\hline 2.4.1.279 & $\begin{array}{l}\text { Nigerose } \\
\text { phosphorylase }\end{array}$ & NP & Glc $\alpha 1 \rightarrow 3 \mathrm{Glc}$ & $\beta G l c 1 P$ & Lachnoclostridium phytofermentans $[5,19]$ \\
\hline 2.4.1.282 & $\begin{array}{l}\text { 3-O- } \alpha \text {-glucosyl-L- } \\
\text { rhamnose } \\
\text { phosphorylase } \\
2-O-\alpha-\end{array}$ & GRP & Glc $\alpha 1 \rightarrow 3 \mathrm{~L}-$ Rham & $\beta$ Glc1P & Lachnoclostridium phytofermentans [25] \\
\hline 2.4.1.332 & $\begin{array}{l}\text { glucosylglycerol } \\
\text { phosphorylase }\end{array}$ & GGP & Glc $\alpha 1 \rightarrow 2$ Glycerol & $\beta$ Glc1P & Salisediminibacterium selenitireducens [26] \\
\hline 2.4.1.334 & $\begin{array}{l}\alpha-1,3 \text {-oligoglucan } \\
\text { phosphorylase }\end{array}$ & oligoNP & Glc $\alpha 1 \rightarrow(3 \mathrm{Glc} \alpha 1 \rightarrow)_{\mathrm{n}-2} 3 \mathrm{Glc}$ & $\beta$ Glc1P & Lachnoclostridium phytofermentans [5] \\
\hline 3.2.1.28 & $\begin{array}{l}\text { Trehalose hydrolase } \\
\text { (trehalase) }\end{array}$ & $\mathrm{TH}$ & Glc $\alpha 1 \rightarrow 1 \alpha$ Glc & Glc & $\begin{array}{l}\text { Saccharomyces cerevisiae [27] } \\
\text { Aspergillus nidulans [28] } \\
\text { Candida albicans [29,30] } \\
\text { Metarhizium anisopliae [31] } \\
\text { Candida parapsilosis [32] } \\
\text { Candida glabrata [33] }\end{array}$ \\
\hline 3.2.1.107 & $\begin{array}{l}\text { Protein- } \alpha \text {-glucosyl- } \\
1,2-\beta \text {-galactosyl-L- } \\
\text { hydroxylysine } \\
\alpha \text {-glucosidase }\end{array}$ & PGGHG & Glc $\alpha 1 \rightarrow 2 \mathrm{Gal} \beta 1 \rightarrow 5 \mathrm{Hyl}$ & Glc & $\begin{array}{l}\text { Gallus gallus [6] } \\
\text { Homo sapiens [6] }\end{array}$ \\
\hline
\end{tabular}

(a)

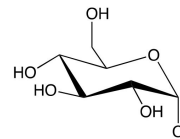

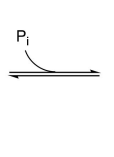

Kojibiose

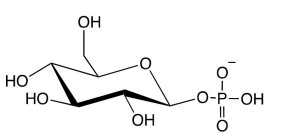

$\beta G l c 1 P$

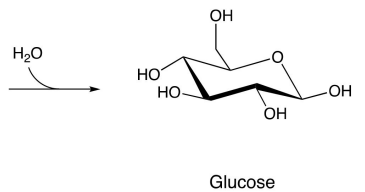

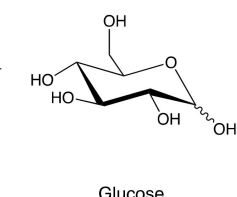

Glucose

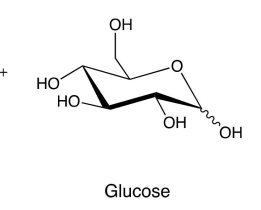

Figure 1. The two types of reactions catalyzed by enzymes in the Glycoside Hydrolase Family 65 (GH65) illustrated by their respective reactions on kojibiose: (a) Reaction catalyzed by kojibiose phosphorylase; (b) Reaction catalyzed by kojibiose hydrolase. $P_{i}$ : inorganic phosphate, $\beta$ Glc1P: $\beta$-D-glucose 1-phosphate.

In the past, efforts have been made to elucidate how substrate specificity is controlled in GH65 enzymes. Yamamoto et al. constructed several chimeric enzymes of the kojibiose phosphorylase (KP) and trehalose phosphorylase (TP) of Thermoanaerobacter brockii. Surprisingly, a certain chimera of 785 amino acids contained only one segment of 125 residues originating from the KP (Met384-Thr512) but still exhibited KP activity. This region, rang- 
ing from $\alpha 3$ to $\alpha 6$ of the $(\alpha, \alpha)_{6}$-barrel catalytic domain, was therefore suspected to contain crucial residues for substrate recognition [34]. Within this region, Nakai et al. identified loop 3, a loop that connects $\alpha 3$ and $\alpha 4$ and forms the rim of the active site, as a potential specificity determinant. Loop 3 is typically conserved within one specificity but highly divergent, both in length and amino acid sequence, between different specificities. Through inspection of the crystal structure and mutational analysis, they were able to identify a three-residue motif within this loop (His413, Asn414 and Glu415 in Lactobacillus acidophilus maltose phosphorylase) that is crucial for maltose binding. Replacing this HNE-motif with the corresponding residues in the KP (TPK) or TP (SAY) of Thermoanaerobacter brockii severely impaired the phosphorolytic activity on maltose, while introducing a low activity on kojibiose or trehalose, respectively [35]. Later, Okada et al. determined the crystal structure of the KP of Caldicellulosiruptor saccharolyticus, which resulted in the discovery of another substrate recognition motif. Three residues (Trp391, Glu392 and Thr417) within loop 3 that bind the glucose moiety of kojibiose in the +1 subsite, are highly conserved within all KPs, but show different motifs in other specificities. However, a specificity switch could not be induced by changing the WET-motif into the patterns observed in maltose-, trehalose- or nigerose-active enzymes [4].

Both motifs identified by Nakai et al. and Okada et al. were based on manual inspection of multiple sequence alignments (MSAs) and analysis of crystal structures. Although they were able to identify crucial residues for maltose resp. kojibiose binding, an in-depth search for specificity determinants of the entire GH65 family has never been performed, as it would be practically impossible to investigate the entire sequence diversity with these ad-hoc methods. However, in the context of sequence annotation, enzyme discovery and specificity engineering, it would be extremely beneficial to identify certain positions in the family's MSA that can be used as an indicator for specificity. Those so-called specificity-determining positions are conserved among all enzymes that share the same specificity but mutate simultaneously across specificity boundaries. If such positions exist, they should be easily picked up by correlated mutations analysis (CMA), a type of statistical analysis that identifies positions in an MSA that underwent interdependent mutations through evolution. As substrate binding is a complex interplay of different residues and interactions, one can expect that a certain function-switching mutation requires one or more compensatory mutations for the protein to remain highly active. These co-evolving positions will thus form a correlation network that can be detected in an MSA through CMA [36].

This technique was already successfully used in the past to uncover specificity fingerprints. Glucokinases could be distinguished from other hexokinases based on six correlated positions that surround the active site [37]. In a similar manner, a network of nine correlated positions was detected in the isocitrate lyase and phosphoenolpyruvate mutase superfamily. One of those nine positions always housed a serine residue in oxaloacetate hydrolases $(\mathrm{OAH})$ and could thus be used as a very specific marker for the OAH subfamily [37]. Bacterial lytic polysaccharide monooxygenases in the Auxiliary Activity Family 10 with activity on cellulose either oxidize exclusively the C1-carbon, or both the C1- and C4-carbon of their substrate. A co-evolving network of 13 positions was shown to be a reliable indicator for this variation in oxidative regioselectivity $[38,39]$. Recently, we described the so-called heptagonal box model for the NDP-sugar active short-chain dehydrogenase/reductase superfamily based on conservation and correlation patterns. The different subfamilies and specificities can be distinguished based on which amino acids occupy the seven "walls" or fingerprint regions of the model [40].

In this work, we used CMA to identify specificity-determining positions for the GH65 family. Visualization of this specificity fingerprint on the family's phylogenetic tree did not only facilitate functional annotation of the sequences in this family, but also uncovered a new enzyme specificity. We describe the discovery of a kojibiose glucohydrolase from the bacterium Mucilaginibacter mallensis. Our work demonstrates the potential of CMA for 
mapping and exploring the natural diversity of an enzyme family and can be beneficial for further explorative endeavors.

\section{Results}

\subsection{Correlated Mutations Analysis}

All sequences in family GH65 were extracted from the CAZy database to build a family alignment. In what follows, the sequence numbering of the kojibiose phosphorylase of Caldicellulosiruptor saccharolyticus (CsKP) will be used to refer to MSA positions, unless stated otherwise. CMA was performed with Comulator [37], which revealed 24 positions in the MSA with a correlation score of 0.8 or higher (Figure 2a). Position 392 clearly holds a central position in the correlation network, with 20 co-evolutionary interactions $(\mathrm{CMA} \geq 0.8)$ detected. All correlated positions are part of the $(\alpha, \alpha)_{6}$-barrel catalytic domain, except for positions 56, 62, 63 and 64, which are located in a loop that emanates from the $\mathrm{N}$-terminal $\beta$-sandwich and is known to be involved in the active site architecture of the Levilactobacillus brevis maltose phosphorylase (Figure 2b) [4]. Some of these residues are found within the active site, while others are further away, with the distance between their $\alpha$-carbon and that of the catalytic acid ranging from 5 to $27 \AA$. For reasons of clarity and simplicity, this selection of correlated positions was further narrowed down. Since both the correlation strength, measured as the CMA score, and the number of correlated partners are important indicators for overall correlation [36], only the six positions with at least one CMA score higher than 0.9 and at least two correlation partners (CMA $\geq 0.8$ ) will be focused on in the rest of the analysis, namely positions 64, 392, 394, 402, 416 and 585.

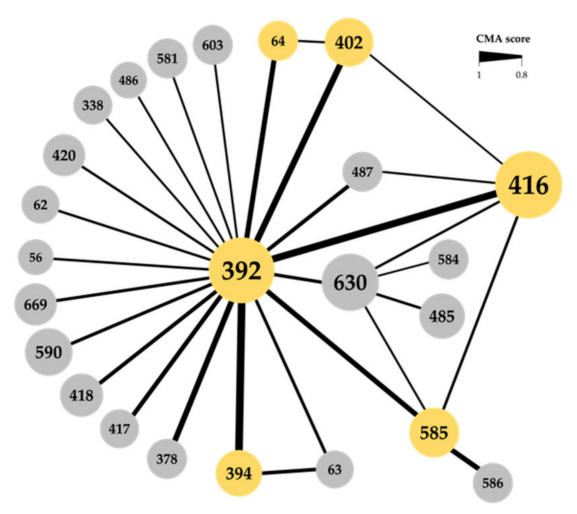

(a)

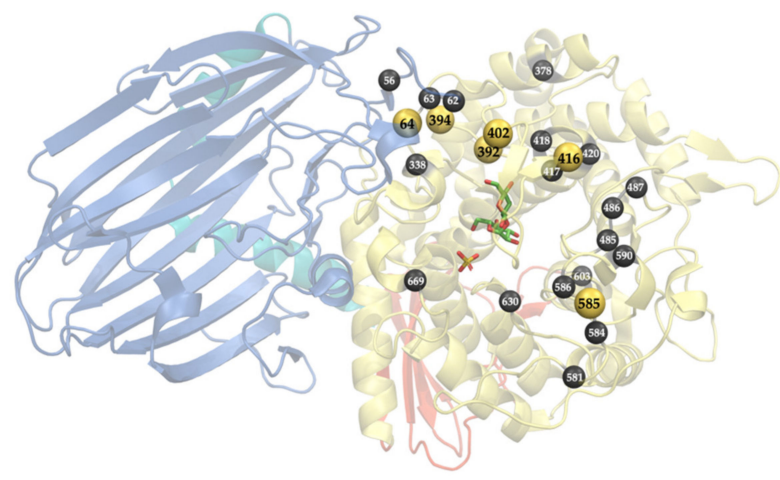

(b)

Figure 2. (a) Correlated position network of the GH65 family alignment, determined with Comulator [37]. Nodes represent the alignment positions, numbering according to the kojibiose phosphorylase of Caldicellulosiruptor saccharolyticus (CsKP). Node size indicates the number of edges. Edge thickness indicates the strength of pair-wise correlation. The six selected positions are highlighted in yellow; (b) Structure of CsKP (PDB ID: 3WIQ) with the location of the correlated positions (yellow and gray spheres). The four structural domains are indicated in different colors: N-terminal domain (blue), linker region (cyan), catalytic domain (yellow) and C-terminal domain (red). Kojibiose (green sticks) and sulphate (yellow sticks) are also shown.

\subsection{Correlated Positions as Specificity Determinants}

The selected correlated positions were visualized on the family's phylogenetic tree by means of colored rings (Figures 3 and S1). The combination of coevolutionary and phylogenetic information was used to divide the entire GH65 family into 22 subgroups. Subgroups that contain enzymes that have previously been characterized experimentally (Table 1) were annotated with the reported substrate specificity. Taking a closer look at the sequence logos of the correlated positions for these subgroups, it is clear that a comparison of the conserved motifs can easily distinguish all specificities (Figures 4 and S2). For example, maltose phosphorylases (MPs) have a highly conserved KV[MF]NES motif, whereas the EEAPxx motif is characteristic of KPs. 
To verify the predictive power of these motifs to act as specificity indicators, four enzymes were selected from different subgroups that already contain annotated representatives. Sequences originating from thermophilic organisms that reside in functionally uncharacterized branches of the subgroups were preferred. The sequences of choice originated from the organisms Thermobispora bispora (TbGP, GenBank ID: ADG89586.1, in subgroup 1), Caldicellulosiruptor hydrothermalis (ChGP, GenBank ID: ADQ05832.1, in subgroup 4), Halothermothrix orenii (HoGP, GenBank ID: ACL68803.1, in subgroup 10.1) and Caldithrix abyssi (CaGP, GenBank ID: APF18594.1, in subgroup 22). Based on their location in the tree and their specificity motifs (TRIGPP, FAITQA, EEAPWS and DQGQDE), they were predicted to be a trehalose phosphorylase (TP), an $\alpha$-1,3-oligoglucan phosphorylase (oligoNP), a kojibiose phosphorylase (KP) and a trehalose-6-phosphate phosphorylase (T6PP), respectively. All four enzymes were expressed in E. coli and purified by means of their His $_{6}$-tag with a yield of 20.2, 41.6, 40.5 and $5.1 \mathrm{mg}$ protein from lysates of a $250 \mathrm{~mL}$-culture, respectively. Their acceptor profile was evaluated by screening them on 46 potential substrates (Table S1). The enzymes were found to show the predicted activity (Figure S3). In a reaction mixture of glucose and $\beta$ Glc1P, TbGP produced trehalose. ChGP elongated nigerose, and other disaccharides, to form $\alpha-1,3$-oligoglucans. HoGP showed typical KP behavior, as it was able to elongate both mono- and disaccharides with $\alpha-1,2$-bound glucose units. In a reaction mixture that contained both kojibiose and $\beta \mathrm{Glc1P}$, phosphorolytic and synthetic reactions co-occur, both breaking kojibiose down to glucose and $\beta$ Glc1P and using it as acceptor to produce $\alpha$-1,2-glucans up to a degree of polymerization (DP) of 6 . Finally, our prediction for $\mathrm{CaGP}$ was also confirmed, as trehalose 6-phosphate was produced from $\beta \mathrm{Glc} 1 \mathrm{P}$ and glucose 6-phosphate.

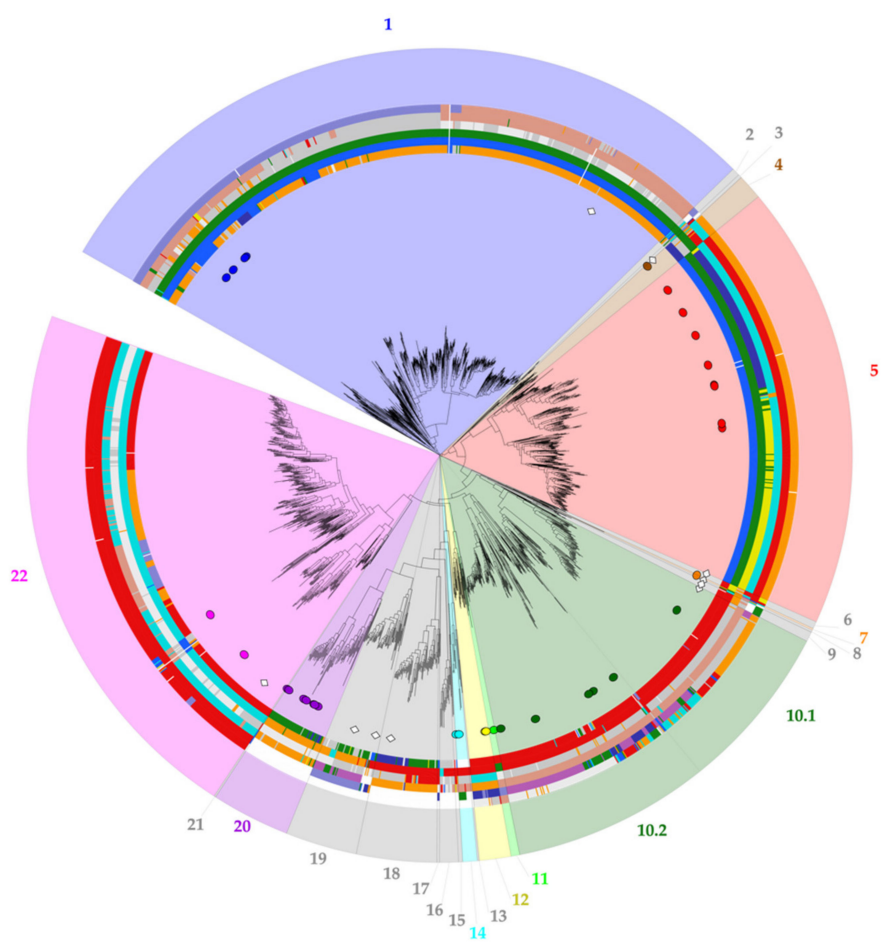

(a)

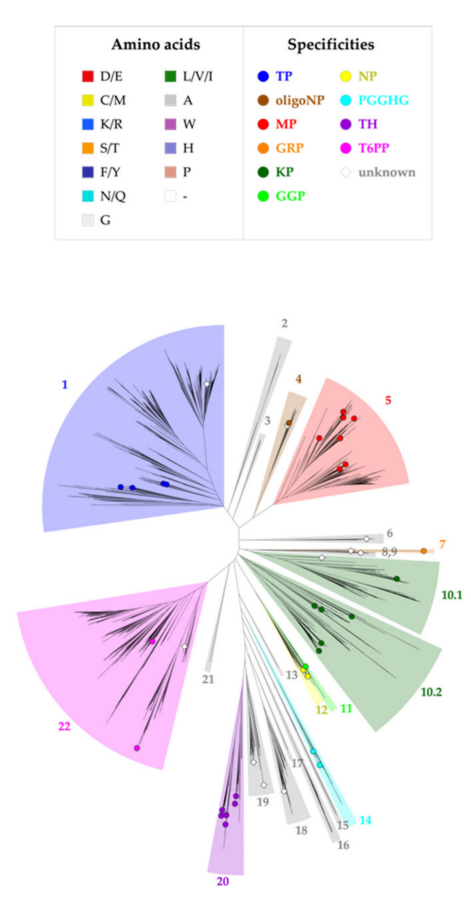

(b)

Figure 3. Phylogenetic tree of family GH65. All annotated representatives and all new enzymes discussed in this study are indicated with circles and diamonds, respectively. The tree is divided into 22 subgroups, which are colored according to their putative specificity. The legend specifies the colors used for each amino acid and each enzyme specificity. (a) Circular tree representation with a visualization of the amino acids present at six correlated positions, shown as colored rings around the phylogenetic tree. From inside to outside, these rings represent positions 64, 392, 394, 402, 416 and 585 (CsKP numbering); (b) Unrooted tree representation. 


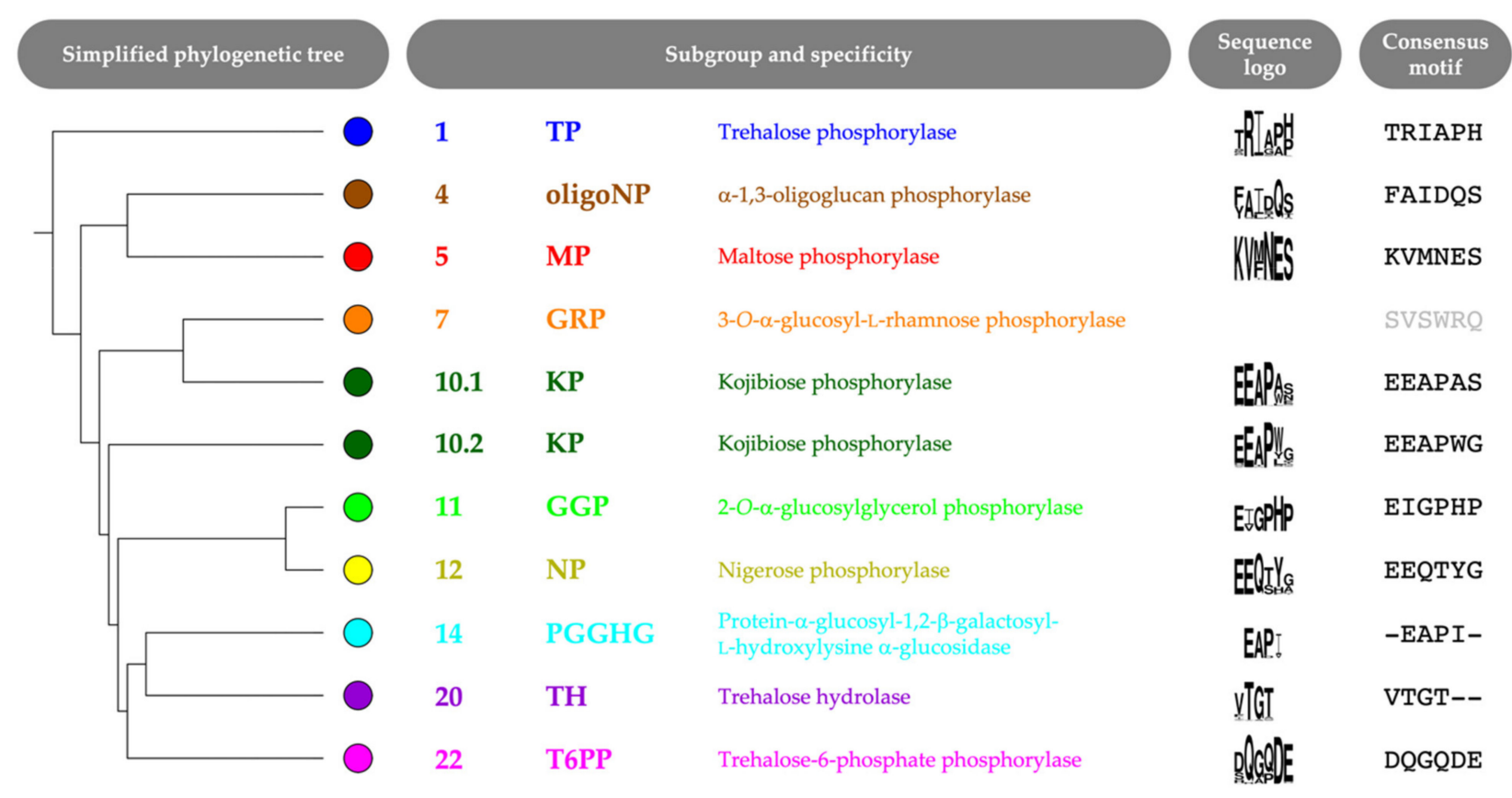

Figure 4. Simplified phylogenetic tree with sequence logo and consensus motif of six correlated positions (left to right, positions 64, 392, 394, 402, 416 and 585; CsKP numbering) for each subgroup that contains characterized GH65 enzymes. A sequence logo for subgroup 7 is not shown, as this branch contains only one sequence (with motif SVSWRQ).

\subsection{Specificity-Determining Correlated Positions as Tool for Enzyme Discovery}

Subgroups 2, 3, 6, 8, 9, 13, 15-19 and 21 could not be annotated as they do not contain any characterized enzymes. Moreover, their sequence motifs at the specificitydetermining correlated positions diverge significantly from those of already described enzymes (Figure S2). These subgroups might contain enzymes with new properties or even new enzyme specificities, and are therefore interesting candidates for further exploration. Six enzymes were selected from such subgroups. Based on the residues that occupy positions known to be involved in phosphate binding [4,41,42], three of them were predicted to be phosphorylases, whereas the other three were predicted to be hydrolases (Figure S4). The three putative glycoside phosphorylases originate from the bacteria Mageeibacillus indolicus (MiGP, GenBank ID: ADC90669.1, in subgroup 6), Kiritimatiella glycovorans (KgGP, GenBank ID: AKJ64725.1, in subgroup 8) and Paenibacillus riograndensis (PrGP, GenBank ID: CQR58226.1, in subgroup 9). The three putative hydrolases originate from the bacteria Mucilaginibacter mallensis (MmGH, GenBank ID: SDT07729.1, in subgroup 18), Phyllobacterium zundukense (PzGH, GenBank ID: ATU91641.1, in subgroup 19) and Streptomyces sp. (StreGH, GenBank ID: AEN12156.1, in subgroup 19). Soluble expression of KgGP, PzGH and StreGH in E. coli was not successful, and these enzymes were thus not further investigated. However, $M i \mathrm{GP}, \operatorname{PrGP}$ and $\mathrm{MmGH}$ did express well and were purified by means of their C-terminal $\mathrm{His}_{6}$-tag, with a yield of 6.2, 17.7 and $26.5 \mathrm{mg}$ protein from lysates of a $250 \mathrm{~mL}$-culture, respectively. The acceptor profile of the putative phosphorylases MiGP and $\operatorname{PrGP}$ was mapped by screening them in the synthesis direction of the reversible reaction on 46 potential acceptor substrates (Table S1). Both enzymes showed activity towards a diverse set of substrates. Apart from minor activity on glucose and galactose, MiGP prefers $\alpha$-glucosidic disaccharides, whereas $\operatorname{PrGP}$ is mainly active on monosaccharides, even on some L-sugars. The results of this acceptor screening did however not give a clear hint for the natural activity of $M i G P$ and $\operatorname{PrGP}$ and their true specificity remains a mystery for now.

The substrate profile of the predicted hydrolase $\mathrm{MmGH}$ was evaluated by screening its activity on nine $\alpha$-glucosides as potential substrates. The enzyme showed very high activity on kojibiose and weak activity on nigerose, but was not capable of breaking down 
trehalose, maltose, isomaltose, sucrose, isomaltulose, turanose or melezitose (Table 2). $\mathrm{MmGH}$ was also able to hydrolyze $\alpha-1,2$-oligoglucans with a higher DP (Figure S5). Based on these results it was hypothesized that kojibiose might be the natural substrate of $\mathrm{MmGH}$ (Figure 1b).

Table 2. Hydrolytic activity of $\mathrm{MmGH}$ on nine potential substrates. Specific activity is reported as mean \pm standard deviation of three independent experiments. Fru: D-fructose, Glc: D-glucose, n.d.: not detected $(<0.01 \mathrm{U} / \mathrm{mg})$.

\begin{tabular}{cccc}
\hline Substrate & Structure & Specific Activity (U/mg) & Relative Activity (\%) \\
\hline Kojibiose & Glc $\alpha 1 \rightarrow 2 \mathrm{Glc}$ & $7.6 \pm 0.3$ & 100 \\
Nigerose & Glc $\alpha 1 \rightarrow 3 \mathrm{Glc}$ & $0.016 \pm 0.001$ & 0.22 \\
Trehalose & Glc $\alpha 1 \rightarrow 1 \alpha \mathrm{Glc}$ & n.d. & - \\
Maltose & Glc $\alpha 1 \rightarrow 4 \mathrm{Glc}$ & n.d. & - \\
Isomaltose & Glc $\alpha 1 \rightarrow 6 \mathrm{Glc}$ & n.d. & - \\
Sucrose & Glc $\alpha 1 \rightarrow 2 \beta \mathrm{Fru}$ & n.d. & - \\
Isomaltulose & Glc $\alpha 1 \rightarrow 6 \mathrm{Fru}$ & n.d. & - \\
Turanose & Glc $\alpha 1 \rightarrow 3 \mathrm{Fru}$ & n.d. & - \\
Melezitose & Glc $\alpha 1 \rightarrow 3 \mathrm{Fru} \beta 2 \rightarrow 1 \mathrm{Glc}$ & n.d. & - \\
\hline
\end{tabular}

${ }^{1}$ Reactions contained $10 \mathrm{mM}$ substrate in $100 \mathrm{mM}$ sodium acetate buffer $(\mathrm{pH} 4.5)$ at $30^{\circ} \mathrm{C}$.

\subsection{Optimal $\mathrm{pH}$ and Temperature and Kinetic Properties of $\mathrm{MmGH}$}

The hydrolytic activity of $\mathrm{MmGH}$ on kojibiose is optimal in a $\mathrm{pH}$ range from 4 to 5.5 (Figure 5a). The optimal $\mathrm{pH}$ range is comparable to that of other hydrolases in family GH65 [27,28,32,33,43-45], but differs from GH65 phosphorylases, which typically prefer neutral $\mathrm{pH}$ values $[5,14,18,19,22,25,26,41]$. The optimal temperature was found to be $30^{\circ} \mathrm{C}$ (Figure 5b), which is at the higher end of the growth range of Mucilaginibacter mallensis (optimal growth at $25^{\circ} \mathrm{C}$ ) [46].

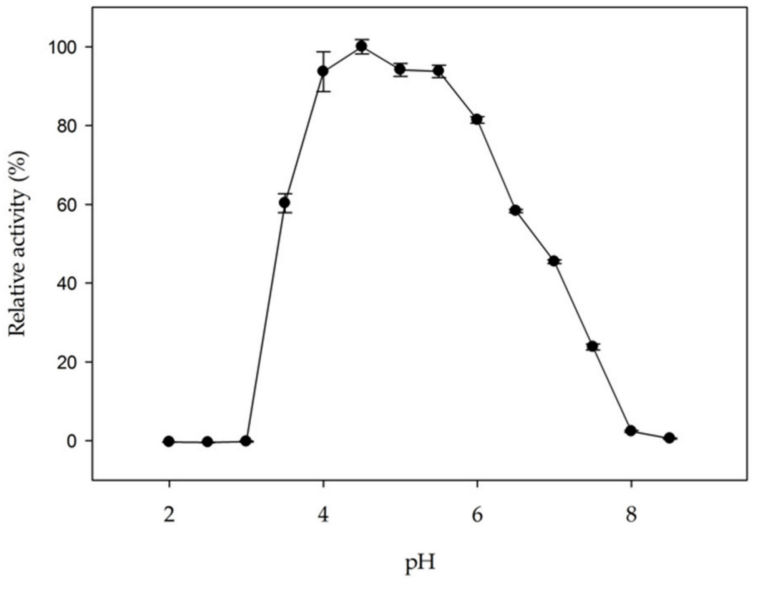

(a)

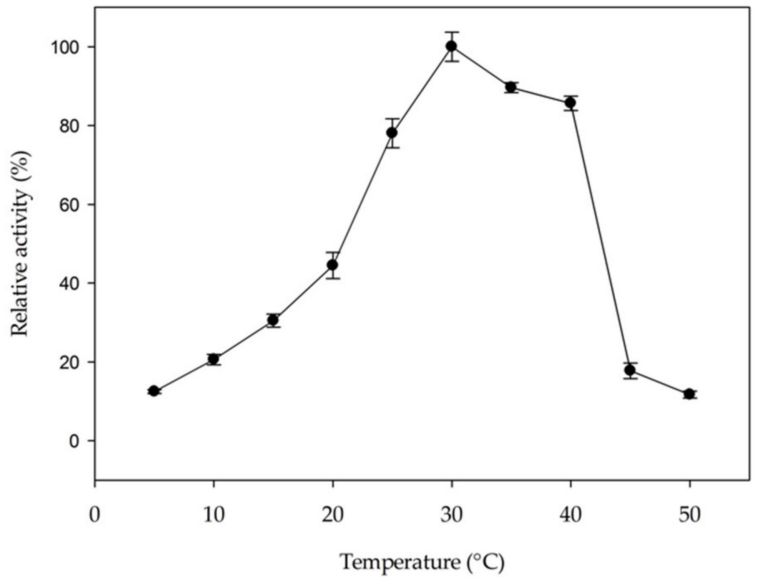

(b)

Figure 5. The effect of (a) $\mathrm{pH}$ and (b) temperature on the hydrolytic activity of $\mathrm{MmGH}$ on kojibiose. Error bars represent standard error from three independent experiments.

The kinetic parameters of $\mathrm{MmGH}$ were determined at the optimal $\mathrm{pH}$ (4.5) and temperature $\left(30^{\circ} \mathrm{C}\right)$. The enzyme exhibited Michaelis-Menten kinetics under these conditions, and $K_{\mathrm{M}}$ and $k_{\text {cat }}$ values of $0.77 \pm 0.01 \mathrm{mM}$ and $9.9 \pm 0.3 \mathrm{~s}^{-1}$ were deduced. The catalytic efficiency $\left(k_{\mathrm{cat}} / K_{\mathrm{M}}\right)$ equals $13 \mathrm{mM}^{-1} \mathrm{~s}^{-1}$. The affinity of $\mathrm{MmGH}$ for kojibiose is higher than that of other GH65 hydrolases for their preferred substrate $\left(K_{\mathrm{M}}\right.$ values between 2.6 and $5.7 \mathrm{mM})[31,33,43,45]$, which further substantiates that kojibiose is indeed the true substrate of this novel hydrolase. 


\section{Discussion}

In this study, we used CMA to uncover distinct sequence patterns that were applied as specificity fingerprints. Our approach allowed us to analyze the entire GH65 family in a systematic, rather than ad-hoc, manner. This is especially important in light of the continuously growing number of sequences available in databases. For instance, the GH65 family contained 1520 sequences in the CAZy database in 2015 [47], whereas this number has increased to 8189 in 2021 (29 August 2021). In earlier work, we already discovered two new enzyme specificities based on rational comparison of sequence motifs, but information about structure-function relationships was required as an input [48,49]. Here, we report how CMA is a relatively easy method to detect specificity-determining positions in large datasets without any prior knowledge required. The described strategy should be readily applicable to other protein families.

The possible applications of CMA are manifold. Firstly, we showed how analysis of correlated mutations allowed protein annotation and phylogenetic tree analysis. Conservation patterns can be used as an indicator for specificity, which can help to predict the activity of unknown sequences and to identify homologues of a certain protein of interest. Visualizing the correlated positions on the phylogenetic tree resulted in an informative and easy-to-read figure, which facilitated annotation of clades in the tree. Furthermore, the identified specificity fingerprint was also demonstrated to be relevant for enzyme discovery. Guided by the conservation patterns, we discovered a dedicated hydrolase for the breakdown of kojibiose. Future efforts for the discovery of novel enzymes in GH65 could focus on elucidating the natural activity of MiGP and $\operatorname{PrGP}$, and the other unexplored subgroups $(2,3,13,15-17$ and 21) are of particular interest as well. Finally, CMA might also be valuable for enzyme engineering endeavors, as it provides insight into non-obvious interactions between residues that would not be easily exposed by manual analysis of sequences and crystal structures [36]. The finding that certain positions are entangled in a co-evolving network should sound a cautionary note for mutating these residues in engineering studies. Substituting an amino acid at one position might require compensatory mutations in other positions in the network. Unwittingly disturbing this network can have a dramatic impact on the enzyme's functionality. This could possibly explain why earlier attempts to mutate positions 392, 402 and 417 of the GH65 correlation network resulted in severely impaired catalytic activity $[4,35]$.

The analysis of correlated positions guided the discovery of a kojibiose hydrolase, for which no EC number is currently available. A few glucosidases have been reported to show some hydrolytic activity on kojibiose, but they typically have a rather relaxed substrate specificity and kojibiose is never their preferred substrate (Table S2). To the best of our knowledge, $\mathrm{MmGH}$ is the first glucosidase that is highly specific for kojibiose. We therefore propose kojibiose glucohydrolase as the systematic name and kojibiose hydrolase or kojibiase as the short name for this new enzyme. Kojibiose is now the second sugar, next to trehalose, for which both a dedicated hydrolase and phosphorylase exist in the GH65 family. Therefore, these would make interesting model enzymes for investigating the evolutionary relationship between glycoside hydrolases and phosphorylases [50], even though they only show $15-25 \%$ sequence identity. Besides its activity on kojibiose, $\mathrm{MmGH}$ is also able to act on $\alpha-1,2$-oligoglucans, an ability it shares with its phosphorylase counterparts [20-23]. MmGH's side-activity on nigerose (0.22\% compared to kojibiose) did not come as a surprise either, as KPs have been reported to phosphorolyze nigerose with a similar relative activity $(0.23-0.73 \%)$ [22,23].

\section{Materials and Methods}

\subsection{Materials}

All chemicals were of analytical grade and were obtained from Sigma-Aldrich/Merck (Darmstadt, Germany) or Carbosynth (Berkshire, United Kingdom), except for psicose (Izumori Lab, Kagawa University, Kagawa, Japan), glycerol (Chem-Lab, Zedelgem, Belgium), tagatose (Nutrilab, Giessen, The Netherlands) and trehalose (Cargill, Vilvoorde, Belgium). 
Kojibiose, nigerose and $\beta \mathrm{Glc} 1 \mathrm{P}$ were produced in-house according to the procedures of Beerens et al. [51], Franceus et al. [52] and Van der Borght et al. [53], respectively.

\subsection{Sequence Analysis}

All protein sequences classified in family GH65 (January 2020) were extracted from the CAZy database (www.cazy.org) [1]. Redundant sequences with more than $90 \%$ sequence identity were removed using CD-HIT with standard parameters [54]. Any annotated GH65 representatives (Table 1) that were removed in this step were added back to the dataset manually. The resulting sequences were aligned with Clustal Omega using default parameters [55]. All 59 sequences lacking the catalytic acid were removed, resulting in a final dataset of 1953 sequences. Those were re-aligned in two steps. First, all characterized GH65 representatives (Table 1) were structurally aligned using MAFFT-DASH [56]. Next, this MSA was used as a skeleton alignment to which the rest of the dataset was aligned with the seed-option of MAFFT [57]. All positions with a gap content of $95 \%$ or higher were removed, resulting in a final MSA of 1490 positions.

A phylogenetic tree was generated with FastTree on the BOOSTER server (https: / / booster.pasteur.fr/) (accessed on 12 January 2021). Branch supports were calculated as transfer bootstrap expectations (TBE) based on 200 bootstrap replicates [58]. The tree was visualized in iTOL [59]. Correlated positions were determined using the Bio-Prodict Comulator tool (https:/ / comulator.bio-prodict.com/) (accessed on 24 January 2021) [37] and visualized as colored rings (RasMol color scheme) around the phylogenetic tree using the built-in function in iTOL. Sequence logos were generated using WebLogo 3 (http:/ / weblogo.threeplusone.com/) (accessed on 19 May 2021) [60]. Figure $2 b$ and Figure S4b were made with PyMOL [61].

\subsection{Gene Cloning and Transformation}

The genes encoding the enzymes expressed in this paper were codon-optimized for E. coli (Table S3), synthesized and subcloned into a pET21a vector at NheI and XhoI restriction sites, introducing a C-terminal His 6 -tag, by GeneArt (Thermo Fisher Scientific, Waltham, MA, USA). The plasmid was used for transformation of E. coli BL21(DE3) agpelectrocompetent cells.

\subsection{Enzyme Expression and Purification}

An overnight culture of the appropriate strain was inoculated $(2 v / v \%)$ in $250 \mathrm{~mL}$ lysogeny broth (LB) medium (10 g/L tryptone, $5 \mathrm{~g} / \mathrm{L}$ yeast extract and $5 \mathrm{~g} / \mathrm{L} \mathrm{NaCl})$ supplemented with $100 \mu \mathrm{g} / \mathrm{mL}$ ampicillin and incubated at $37^{\circ} \mathrm{C}$ with continuous shaking at $200 \mathrm{rpm}$ until the $\mathrm{OD}_{600}$ reached $\sim 0.6$. Subsequently, enzyme expression from the pET21a vector was induced by adding isopropyl $\beta$-D-thiogalactopyranoside (IPTG) to a final concentration of $0.1 \mathrm{mM}$ and continuing incubation at $20{ }^{\circ} \mathrm{C}$ overnight. Cells were harvested by centrifugation ( $30 \mathrm{~min}$ at $9000 \mathrm{rpm}$ and $4{ }^{\circ} \mathrm{C}$ ). Cell pellets were frozen at $-20{ }^{\circ} \mathrm{C}$ for at least one hour. For enzyme extraction and purification, the pellet of a $250 \mathrm{~mL}$ culture was resuspended in $8 \mathrm{~mL}$ of lysis buffer ( $10 \mathrm{mM}$ imidazole, $100 \mu \mathrm{M}$ phenylmethanesulfonyl fluoride (PMSF), $1 \mathrm{mg} / \mathrm{mL}$ lysozyme, $500 \mathrm{mM} \mathrm{NaCl}, 50 \mathrm{mM}$ sodium phosphate, $\mathrm{pH} 7.4$ ) and cooled on ice for $30 \mathrm{~min}$. The resulting suspension was sonicated 2 times 3 min (Branson sonifier 450, level 3,50\% duty cycle). Next, the crude cell extract was separated from the cell debris by centrifugation (30 min at $9000 \mathrm{rpm}$ and $4{ }^{\circ} \mathrm{C}$ ) and subsequently purified by nickel-nitrilotriacetic acid (Ni-NTA) affinity chromatography. The HisPur ${ }^{\mathrm{TM}}$ Ni-NTA resin (1.5 mL, Thermo Fisher Scientific) was washed with $8 \mathrm{~mL}$ water and equilibrated twice with $8 \mathrm{~mL}$ equilibration buffer $(10 \mathrm{mM}$ imidazole, $500 \mathrm{mM}$ $\mathrm{NaCl}, 50 \mathrm{mM}$ sodium phosphate, $\mathrm{pH} 7.4$ ) before the crude cell extract was added to allow binding to the resin. Next, the resin was washed three times with $8 \mathrm{~mL}$ wash buffer ( $30 \mathrm{mM}$ imidazole, $500 \mathrm{mM} \mathrm{NaCl}, 50 \mathrm{mM}$ sodium phosphate, $\mathrm{pH}$ 7.4). Protein was eluted with $8 \mathrm{~mL}$ elution buffer $(250 \mathrm{mM}$ imidazole, $500 \mathrm{mM} \mathrm{NaCl}, 50 \mathrm{mM}$ sodium phosphate, $\mathrm{pH}$ 7.4). The buffer was exchanged to $50 \mathrm{mM} 3$-( $N$-morpholino)propanesulfonic 
acid (MOPS) (pH 7.0) using a $30 \mathrm{kDa}$ cut-off Amicon centrifugal filter unit (Millipore). The protein content was determined by measuring the absorbance at $280 \mathrm{~nm}$ with the NanoDrop 2000 spectrophotometer (Thermo Fisher Scientific). The extinction coefficient and molecular weight of $\mathrm{His}_{6}$-tagged enzymes were calculated using the ProtParam tool on the ExPASy server (https://web.expasy.org/protparam/) (accessed on 24 February 2021). Molecular weight and purity of the protein were verified by sodium dodecyl sulfate polyacrylamide gel electrophoresis (SDS-PAGE; $10 \%$ gel).

\subsection{Detection of Reaction Components}

Phosphorylase activity was monitored in the synthetic direction of the reversible reaction by measuring the release of inorganic phosphate using the phosphomolybdate assay described by Gawronski and Benson (2004) [62]. Hydrolytic activity was monitored by the release of glucose, which could be quantified with an enzymatic coupled assay using glucose oxidase and peroxidase (GOD-POD) [63]. The assay solution contained $0.45 \mathrm{mg} / \mathrm{mL}$ GOD, $69.2 \mu \mathrm{g} / \mathrm{mL}$ POD and $0.5 \mathrm{mg} / \mathrm{mL}$ 2,2'-azino-bis(3-ethylbenzthiazoline6-sulfonic acid) (ABTS) in $1 \mathrm{M}$ acetate buffer ( $\mathrm{pH} 4.5)$. As the $\mathrm{pH}$ of the assay solution was not sufficient to inactivate $M m \mathrm{GH}$, samples $(25 \mu \mathrm{L})$ were first inactivated with $1 \mathrm{M}$ $\mathrm{NaOH}(25 \mu \mathrm{L})$ before adding $200 \mu \mathrm{L}$ of the assay solution. After $30 \mathrm{~min}$ incubation at $37^{\circ} \mathrm{C}$, absorbance was measured at $420 \mathrm{~nm}$. Reactions were also monitored by high-performance anion exchange chromatography (HPAEC), coupled to a pulsed amperometric detection (PAD) system. A Dionex ICS-3000 (Thermo Fisher Scientific) with a CarboPac PA20 pHstable column was used. A $5-\mu \mathrm{L}$ heat-inactivated $\left(10 \mathrm{~min}\right.$ at $\left.95^{\circ} \mathrm{C}\right)$ and appropriately diluted sample was analyzed at a constant flow rate of $0.5 \mathrm{~mL} / \mathrm{min}$ at $30^{\circ} \mathrm{C}$. The eluent always contained $100 \mathrm{mM} \mathrm{NaOH}$, but the concentration of sodium acetate linearly increased from $10 \mathrm{mM}$ at the start to $600 \mathrm{mM}$ after $18 \mathrm{~min}$. This composition was maintained for $1 \mathrm{~min}$, after which the acetate concentration was gradually changed back to $10 \mathrm{mM}$ during $2 \mathrm{~min}$. After reaching this initial composition, the run continued for $4 \mathrm{~min}$.

\subsection{Screening of Potential Substrates}

The acceptor profile of the selected glycoside phosphorylases was evaluated by screening them on 46 potential acceptors (Table S4) using the phosphomolybdate assay. Reactions were performed with $10 \mathrm{mM} \beta \mathrm{Glc} 1 \mathrm{P}, 10 \mathrm{mM}$ of the acceptor and $0.1 \mathrm{mg} / \mathrm{mL}$ purified enzyme in $50 \mathrm{mM}$ MOPS buffer ( $\mathrm{pH}$ 7.0) at room temperature. For all hits, the same reaction was repeated at $30^{\circ} \mathrm{C}$ and $1000 \mathrm{rpm}$ and analyzed with HPAEC-PAD to dismiss any false positives.

For $M m \mathrm{GH}$, nine compounds (trehalose, kojibiose, nigerose, maltose, isomaltose, isomaltulose, sucrose, turanose and melezitose) were evaluated as potential substrates. Reactions were performed with $10 \mathrm{mM}$ of the substrate and $0.5 \mathrm{mg} / \mathrm{mL}$ purified enzyme in $100 \mathrm{mM}$ sodium acetate buffer (pH 4.5) at room temperature. Samples were taken every $2 \mathrm{~min}$ for $16 \mathrm{~min}$ and were analyzed with the GOD-POD assay. For kojibiose, this reaction was repeated with $5 \mu \mathrm{g} / \mathrm{mL}$ purified enzyme to ensure measurement of the initial velocity. For all hits, the same reaction was repeated at $30^{\circ} \mathrm{C}$ and $1000 \mathrm{rpm}$ and analyzed with HPAEC-PAD to dismiss any false positives. To evaluate $\mathrm{MmGH}$ 's activity on $\alpha$-1,2-oligoglucans, a mixture of kojitriose $(\sim 90 \%)$ and kojitetraose $(\sim 9 \%)$ was produced with CsKP [22]. A reaction was performed with $\sim 50 \mathrm{mM}$ kojitriose, $\sim 5 \mathrm{mM}$ kojitetraose and $0.1 \mathrm{mg} / \mathrm{mL}$ purified enzyme in $100 \mathrm{mM}$ sodium acetate buffer $(\mathrm{pH} 4.5)$ at $30^{\circ} \mathrm{C}$ and $1000 \mathrm{rpm}$. Samples were analyzed with HPAEC-PAD.

\subsection{Optimal $\mathrm{pH}$ and Temperature and Kinetic Properties of $\mathrm{MmGH}$}

The influence of $\mathrm{pH}$ on enzyme activity was determined in $100 \mathrm{mM}$ Mcllvaine buffer ( $\mathrm{pH}$ 2.5-4.0), $100 \mathrm{mM}$ sodium acetate buffer ( $\mathrm{pH} 4.5-5.0), 100 \mathrm{mM}$ 2-(N-morpholino)ethanesulfonic acid (MES) buffer (pH 5.5-6.5), $100 \mathrm{mM}$ MOPS buffer (pH 7.0-7.5) or $100 \mathrm{mM}$ tris(hydroxymethyl)aminomethane-hydrochloride (Tris- $\mathrm{HCl}$ ) buffer $(\mathrm{pH} 8.0-8.5)$ at $30^{\circ} \mathrm{C}$. The optimal temperature was determined in $100 \mathrm{mM}$ sodium acetate buffer (pH 4.5). For 
each reaction, $5 \mu \mathrm{g} / \mathrm{mL}$ purified enzyme was incubated with $50 \mathrm{mM}$ kojibiose. Samples were taken every $2 \mathrm{~min}$ for $16 \mathrm{~min}$ and analyzed with the GOD-POD assay.

The apparent kinetic parameters of $\mathrm{MmGH}$ for kojibiose were determined at the optimal temperature $\left(30^{\circ} \mathrm{C}\right)$ and $\mathrm{pH}(4.5)$ in $100 \mathrm{mM}$ sodium acetate buffer. MichaelisMenten curves were obtained using $5 \mu \mathrm{g} / \mathrm{mL}$ purified enzyme and varying kojibiose concentrations $(0.25-10 \mathrm{mM})$. Parameters were calculated by non-linear regression of the Michaelis-Menten equation using SigmaPlot 13. The molecular weight (73.7 kDa) was used to calculate the turnover number $k_{\text {cat }}$. All tests were performed in triplicate. One unit of enzyme activity was defined as the amount of enzyme hydrolyzing one $\mu \mathrm{mol}$ of substrate per minute under the specified conditions.

Supplementary Materials: The following are available online, Figure S1: Phylogenetic tree of family GH65 with a visualization of the amino acids present at 24 correlated positions, Figure S2: Simplified phylogenetic tree with sequence logo of 24 correlated positions, Figure S3: Reaction profile of selected GH65 glycoside phosphorylases in the synthetic direction of the reversible reaction, Figure S4: Glycoside phosphorylases and hydrolases in family GH65, Figure S5: Hydrolysis of $\alpha-1,2$-oligoglucans by $\mathrm{M} m \mathrm{GH}$, Table S1: Acceptor profile of six GH65 glycoside phosphorylases in the synthetic direction of the reversible reaction, Table S2: Comparison of the substrate profile of all $\alpha$-glucosidases with hydrolytic activity on kojibiose reported in the BRENDA database and $\mathrm{MmGH}$, Table S3: Nucleotide sequences encoding the enzymes expressed in this work, Table S4: Overview of all compounds tested as possible acceptor for the selected GH65 glycoside phosphorylases [64-88].

Author Contributions: Conceptualization, E.D.B., J.F. and T.D.; investigation, E.D.B. and A.J.; writing—original draft preparation, E.D.B.; writing—review and editing, J.F. and T.D.; visualization, E.D.B.; supervision, T.D. All authors have read and agreed to the published version of the manuscript.

Funding: This research was funded by Research Foundation-Flanders (FWO), grant number 1S17721N (doctoral scholarship for E.D.B.).

Institutional Review Board Statement: Not applicable.

Informed Consent Statement: Not applicable.

Data Availability Statement: The data are available within this article and its Supplementary Materials.

Conflicts of Interest: The authors declare no conflict of interest. The funders had no role in the design of the study; in the collection, analyses, or interpretation of data; in the writing of the manuscript, or in the decision to publish the results.

Sample Availability: The plasmid for expression of $\mathrm{MmGH}$ has been deposited at BCCM/GeneCorner Plasmid Collec-tion (accession number: LMBP 13040) and is thus publicly available.

\section{References}

1. Lombard, V.; Golaconda Ramulu, H.; Drula, E.; Coutinho, P.M.; Henrissat, B. The carbohydrate-active enzymes database (CAZy) in 2013. Nucleic Acids Res. 2014, 42, D490-D495. [CrossRef]

2. Sun, S.; You, C. Disaccharide phosphorylases: Structure, catalytic mechanisms and directed evolution. Synth. Syst. Biotechnol. 2021, 6, 23-31. [CrossRef] [PubMed]

3. Desmet, T.; Soetaert, W. Enzymatic glycosyl transfer: Mechanisms and applications. Biocatal. Biotransform. 2011, 29 , 1-18. [CrossRef]

4. Okada, S.; Yamamoto, T.; Watanabe, H.; Nishimoto, T.; Chaen, H.; Fukuda, S.; Wakagi, T.; Fushinobu, S. Structural and mutational analysis of substrate recognition in kojibiose phosphorylase. FEBS J. 2014, 281, 778-786. [CrossRef] [PubMed]

5. Nihira, T.; Nishimoto, M.; Nakai, H.; Ohtsubo, K.; Kitaoka, M. Characterization of Two $\alpha-1$,3-Glucoside Phosphorylases from Clostridium phytofermentans. J. Appl. Glycosci. 2014, 61, 59-66. [CrossRef]

6. Hamazaki, H.; Hamazaki, M.H. Catalytic site of human protein-glucosylgalactosylhydroxylysine glucosidase: Three crucial carboxyl residues were determined by cloning and site-directed mutagenesis. Biochem. Biophys. Res. Commun. 2016, 469, 357-362. [CrossRef] [PubMed]

7. Hüwel, S.; Haalck, L.; Conrath, N.; Spener, F. Maltose phosphorylase from Lactobacillus brevis: Purification, characterization, and application in a biosensor for ortho-phosphate. Enzyme Microb. Technol. 1997, 21, 413-420. [CrossRef]

8. Ehrmann, M.A.; Vogel, R.F. Maltose metabolism of Lactobacillus sanfranciscensis: Cloning and heterologous expression of the key enzymes, maltose phosphorylase and phosphoglucomutase. FEMS Microbiol. Lett. 1998, 169, 81-86. [CrossRef] [PubMed] 
9. Inoue, Y.; Yasutake, N.; Oshima, Y.; Yamamoto, Y.; Tomita, T.; Miyoshi, S.; Yatake, T. Cloning of the Maltose Phosphorylase Gene from Bacillus sp. Strain RK-1 and Efficient Production of the Cloned Gene and the Trehalose Phosphorylase Gene from Bacillus stearothermophilus SK-1 in Bacillus subtilis. Biosci. Biotechnol. Biochem. 2002, 66, 2594-2599. [CrossRef]

10. Hidaka, Y.; Hatada, Y.; Akita, M.; Yoshida, M.; Nakamura, N.; Takada, M.; Nakakuki, T.; Ito, S.; Horikoshi, K. Maltose phosphorylase from a deep-sea Paenibacillus sp.: Enzymatic properties and nucleotide and amino-acid sequences. Enzyme Microb. Technol. 2005, 37, 185-194. [CrossRef]

11. Nakai, H.; Baumann, M.J.; Petersen, B.O.; Westphal, Y.; Schols, H.; Dilokpimol, A.; Hachem, M.A.; Lahtinen, S.J.; Duus, J.Ø.; Svensson, B. The maltodextrin transport system and metabolism in Lactobacillus acidophilus NCFM and production of novel $\alpha$-glucosides through reverse phosphorolysis by maltose phosphorylase. FEBS J. 2009, 276, 7353-7365. [CrossRef] [PubMed]

12. Nihira, T.; Saito, Y.; Kitaoka, M.; Otsubo, K.; Nakai, H. Identification of Bacillus selenitireducens MLS10 maltose phosphorylase possessing synthetic ability for branched $\alpha$-D-glucosyl trisaccharides. Carbohydr. Res. 2012, 360, 25-30. [CrossRef] [PubMed]

13. Mokhtari, A.; Blancato, V.S.; Repizo, G.D.; Henry, C.; Pikis, A.; Bourand, A.; de Fátima Álvarez, M.; Immel, S.; Mechakra-Maza, A.; Hartke, A.; et al. Enterococcus faecalis utilizes maltose by connecting two incompatible metabolic routes via a novel maltose 6'-phosphate phosphatase (MapP). Mol. Microbiol. 2013, 88, 234-253. [CrossRef]

14. Chaen, H.; Nakada, T.; Nishimoto, T.; Kuroda, N.; Fukuda, S.; Sugimoto, T.; Kurimoto, M.; Yoshio, T. Purification and characterization of thermostable trehalose phosphorylase from Thermoanaerobium brockii. J. Appl. Glycosci. 1999, 46, 399-405. [CrossRef]

15. Inoue, Y.; Ishii, K.; Tomita, T.; Yatake, T.; Fukui, F. Characterization of trehalose phosphorylase from Bacillus stearothermophilus SK-1 and nucleotide sequence of the corresponding gene. Biosci. Biotechnol. Biochem. 2002, 66, 1835-1843. [CrossRef] [PubMed]

16. Van der Borght, J.; Chen, C.; Hoflack, L.; Van Renterghem, L.; Desmet, T.; Soetaert, W. Enzymatic properties and substrate specificity of the trehalose phosphorylase from Caldanaerobacter subterraneus. Appl. Environ. Microbiol. 2011, 77, 6939-6944. [CrossRef]

17. Nihira, T.; Saito, Y.; Chiku, K.; Kitaoka, M.; Ohtsubo, K.; Nakai, H. Potassium ion-dependent trehalose phosphorylase from halophilic Bacillus selenitireducens MLS10. FEBS Lett. 2013, 587, 3382-3386. [CrossRef]

18. Andersson, U.; Levander, F.; Rådström, P. Trehalose-6-phosphate Phosphorylase Is Part of a Novel Metabolic Pathway for Trehalose Utilization in Lactococcus lactis. J. Biol. Chem. 2001, 276, 42707-42713. [CrossRef] [PubMed]

19. Nihira, T.; Nakai, H.; Chiku, K.; Kitaoka, M. Discovery of nigerose phosphorylase from Clostridium phytofermentans. Appl. Microbiol. Biotechnol. 2012, 93, 1513-1522. [CrossRef]

20. Chaen, H.; Yamamoto, T.; Nishimoto, T.; Nakada, T.; Fukuda, S.; Sugimoto, T.; Kurimoto, M.; Tsujisaka, Y. Purification and Characterization of a Novel Phosphorylase, Kojibiose Phosphorylase, from Thermoanaerobium brockii. J. Appl. Glycosci. 1999, 46, 423-429. [CrossRef]

21. Yamamoto, T.; Maruta, K.; Mukai, K.; Yamashita, H.; Nishimoto, T.; Kubota, M.; Fukuda, S.; Kurimoto, M.; Tsujisaka, Y. Cloning and sequencing of kojibiose phosphorylase gene from Thermoanaerobacter brockii ATCC35047. J. Biosci. Bioeng. 2004, 98, 99-106. [CrossRef]

22. Yamamoto, T.; Nishio-Kosaka, M.; Izawa, S.; Aga, H.; Nishimoto, T.; Chaen, H.; Fukuda, S. Enzymatic properties of recombinant kojibiose phosphorylase from Caldicellulosiruptor saccharolyticus ATCC43494. Biosci. Biotechnol. Biochem. 2011, 75, 1208-1210. [CrossRef]

23. Jung, J.H.; Seo, D.H.; Holden, J.F.; Park, C.S. Identification and characterization of an archaeal kojibiose catabolic pathway in the hyperthermophilic Pyrococcus sp. strain ST04. J. Bacteriol. 2014, 196, 1122-1131. [CrossRef]

24. Mukherjee, K.; Narindoshvili, T.; Raushel, F.M. Discovery of a Kojibiose Phosphorylase in Escherichia coli K-12. Biochemistry 2018, 57, 2857-2867. [CrossRef] [PubMed]

25. Nihira, T.; Nakai, H.; Kitaoka, M. 3-O- $\alpha$-D-glucopyranosyl-L-rhamnose phosphorylase from Clostridium phytofermentans. Carbohydr. Res. 2012, 350, 94-97. [CrossRef] [PubMed]

26. Nihira, T.; Saito, Y.; Ohtsubo, K.; Nakai, H.; Kitaoka, M. 2-O- $\alpha$-D-Glucosylglycerol Phosphorylase from Bacillus selenitireducens MLS10 Possessing Hydrolytic Activity on $\beta$-D-Glucose 1-Phosphate. PLoS ONE 2014, 9, e86548. [CrossRef] [PubMed]

27. Alizadeh, P.; Klionsky, D.J. Purification and biochemical characterization of the ATH1 gene product, vacuolar acid trehalase, from Saccharomyces cerevisiae. FEBS Lett. 1996, 391, 273-278. [CrossRef]

28. D'Enfert, C.; Fontaine, T. Molecular characterization of the Aspergillus nidulans treA gene encoding an acid trehalase required for growth on trehalose. Mol. Microbiol. 1997, 24, 203-216. [CrossRef]

29. Weinstock, K.G.; Bush, D. Nucleic Acid Sequences Relating to Candida albicans for Diagnostics and Therapeutics. U.S. Patent US6747137, 12 February 1999.

30. Pedreño, Y.; Maicas, S.; Argüelles, J.C.; Sentandreu, R.; Valentin, E. The ATC1 gene encodes a cell wall-linked acid trehalase required for growth on trehalose in Candida albicans. J. Biol. Chem. 2004, 279, 40852-40860. [CrossRef] [PubMed]

31. Liu, Y.; Wang, Z.; Yin, Y.; Cao, Y.; Zhao, H.; Xia, Y. Expression, purification, and characterization of recombinant Metarhizium anisopliae acid trehalase in Pichia pastoris. Protein Expr. Purif. 2007, 54, 66-72. [CrossRef] [PubMed]

32. Sánchez-Fresneda, R.; Martínez-Esparza, M.; Maicas, S.; Argüelles, J.-C.; Valentín, E. In Candida parapsilosis the ATC1 Gene Encodes for an Acid Trehalase Involved in Trehalose Hydrolysis, Stress Resistance and Virulence. PLoS ONE 2014, 9, e99113. [CrossRef] 
33. Zilli, D.M.W.; Lopes, R.G.; Alves, S.L.; Barros, L.M.; Miletti, L.C.; Stambuk, B.U. Secretion of the acid trehalase encoded by the CgATH1 gene allows trehalose fermentation by Candida glabrata. Microbiol. Res. 2015, 179, 12-19. [CrossRef] [PubMed]

34. Yamamoto, T.; Yamashita, H.; Mukai, K.; Watanabe, H.; Kubota, M.; Chaen, H.; Fukuda, S. Construction and characterization of chimeric enzymes of kojibiose phosphorylase and trehalose phosphorylase from Thermoanaerobacter brockii. Carbohydr. Res. 2006, 341, 2350-2359. [CrossRef] [PubMed]

35. Nakai, H.; Petersen, B.O.; Westphal, Y.; Dilokpimol, A.; Abou Hachem, M.; Duus, J.Ø.; Schols, H.A.; Svensson, B. Rational engineering of Lactobacillus acidophilus NCFM maltose phosphorylase into either trehalose or kojibiose dual specificity phosphorylase. Protein Eng. Des. Sel. 2010, 23, 781-787. [CrossRef]

36. Franceus, J.; Verhaeghe, T.; Desmet, T. Correlated positions in protein evolution and engineering. J. Ind. Microbiol. Biotechnol. 2017, 44, 687-695. [CrossRef]

37. Kuipers, R.K.P.; Joosten, H.-J.; Verwiel, E.; Paans, S.; Akerboom, J.; van der Oost, J.; Leferink, N.G.H.; van Berkel, W.J.H.; Vriend, G.; Schaap, P.J. Correlated mutation analyses on super-family alignments reveal functionally important residues. Proteins Struct. Funct. Bioinform. 2009, 76, 608-616. [CrossRef]

38. Forsberg, Z.; Bissaro, B.; Gullesen, J.; Dalhus, B.; Vaaje-Kolstad, G.; Eijsink, V.G.H. Structural determinants of bacterial lytic polysaccharide monooxygenase functionality. J. Biol. Chem. 2018, 293, 1397-1412. [CrossRef] [PubMed]

39. Forsberg, Z.; Stepnov, A.A.; Nærdal, G.K.; Klinkenberg, G.; Eijsink, V.G.H. Engineering lytic polysaccharide monooxygenases (LPMOs). Methods Enzymol. 2020, 644, 1-34. [CrossRef] [PubMed]

40. Da Costa, M.; Gevaert, O.; Van Overtveldt, S.; Lange, J.; Joosten, H.J.; Desmet, T.; Beerens, K. Structure-function relationships in NDP-sugar active SDR enzymes: Fingerprints for functional annotation and enzyme engineering. Biotechnol. Adv. 2021, 48, 107705. [CrossRef]

41. Egloff, M.P.; Uppenberg, J.; Haalck, L.; van Tilbeurgh, H. Crystal structure of maltose phosphorylase from Lactobacillus brevis: Unexpected evolutionary relationship with glucoamylases. Structure 2001, 9, 689-697. [CrossRef]

42. Touhara, K.K.; Nihira, T.; Kitaoka, M.; Nakai, H.; Fushinobu, S. Structural basis for reversible phosphorolysis and hydrolysis reactions of 2-O- $\alpha$-Glucosylglycerol phosphorylase. J. Biol. Chem. 2014, 289, 18067-18075. [CrossRef]

43. Mittenbuhler, K.; Holzer, H. Purification and characterization of acid trehalase from the yeast suc2 mutant. J. Biol. Chem. 1988, 263, 8537-8543. [CrossRef]

44. Destruelle, M.; Holzer, H.; Klionsky, D.J. Isolation and characterization of a novel yeast gene, ATH1, that is required for vacuolar acid trehalase activity. Yeast 1995, 11, 1015-1025. [CrossRef] [PubMed]

45. Sternberg, M.; Spiro, R.G. Studies on the Catabolism of the Hydroxylysine-Linked Disaccharide Units of Basement Membranes and Collagens. Ren. Physiol. 1980, 3, 1-3. [CrossRef]

46. Männistö, M.K.; Tiirola, M.; McConnell, J.; Häggblom, M.M. Mucilaginibacter frigoritolerans sp. nov., Mucilaginibacter lappiensis sp. nov. and Mucilaginibacter mallensis sp. nov., isolated from soil and lichen samples. Int. J. Syst. Evol. Microbiol. 2010, 60, 2849-2856. [CrossRef]

47. Kitaoka, M. Diversity of phosphorylases in glycoside hydrolase families. Appl. Microbiol. Biotechnol. 2015, 99, 8377-8390. [CrossRef] [PubMed]

48. Franceus, J.; Decuyper, L.; D’hooghe, M.; Desmet, T. Exploring the sequence diversity in glycoside hydrolase family 13_18 reveals a novel glucosylglycerol phosphorylase. Appl. Microbiol. Biotechnol. 2018, 102, 3183-3191. [CrossRef] [PubMed]

49. Franceus, J.; Pinel, D.; Desmet, T. Glucosylglycerate Phosphorylase, an Enzyme with Novel Specificity Involved in Compatible Solute Metabolism. Appl. Environ. Microbiol. 2017, 83, e01434-17. [CrossRef] [PubMed]

50. Franceus, J.; Lormans, J.; Cools, L.; D’hooghe, M.; Desmet, T. Evolution of Phosphorylases from N-Acetylglucosaminide Hydrolases in Family GH3. ACS Catal. 2021, 11, 6225-6233. [CrossRef]

51. Beerens, K.; De Winter, K.; Van de Walle, D.; Grootaert, C.; Kamiloglu, S.; Miclotte, L.; Van de Wiele, T.; Van Camp, J.; Dewettinck, K.; Desmet, T. Biocatalytic synthesis of the rare sugar kojibiose: Process scale-up and application testing. J. Agric. Food Chem. 2017, 65, 6030-6041. [CrossRef] [PubMed]

52. Franceus, J.; Dhaene, S.; Decadt, H.; Vandepitte, J.; Caroen, J.; Van der Eycken, J.; Beerens, K.; Desmet, T. Rational design of an improved transglucosylase for production of the rare sugar nigerose. Chem. Commun. 2019, 55, 4531-4533. [CrossRef] [PubMed]

53. Van der Borght, J.; Desmet, T.; Soetaert, W. Enzymatic production of $\beta$-D-glucose-1-phosphate from trehalose. Biotechnol. J. 2010, 5, 986-993. [CrossRef]

54. Huang, Y.; Niu, B.; Gao, Y.; Fu, L.; Li, W. CD-HIT Suite: A web server for clustering and comparing biological sequences. Bioinformatics 2010, 26, 680-682. [CrossRef] [PubMed]

55. Sievers, F.; Higgins, D.G. Clustal Omega for making accurate alignments of many protein sequences. Protein Sci. 2018, 27, 135-145. [CrossRef]

56. Rozewicki, J.; Li, S.; Amada, K.M.; Standley, D.M.; Katoh, K. MAFFT-DASH: Integrated protein sequence and structural alignment. Nucleic Acids Res. 2019, 47, W5-W10. [CrossRef] [PubMed]

57. Katoh, K.; Toh, H. Recent developments in the MAFFT multiple sequence alignment program. Brief. Bioinf. 2008, 9, 286-298. [CrossRef] [PubMed]

58. Lemoine, F.; Domelevo Entfellner, J.B.; Wilkinson, E.; Correia, D.; Dávila Felipe, M.; De Oliveira, T.; Gascuel, O. Renewing Felsenstein's phylogenetic bootstrap in the era of big data. Nature 2018, 556, 452-456. [CrossRef] [PubMed] 
59. Letunic, I.; Bork, P. Interactive Tree Of Life (iTOL) v5: An online tool for phylogenetic tree display and annotation. Nucleic Acids Res. 2021, 49, W293-W296. [CrossRef]

60. Crooks, G.E.; Hon, G.; Chandonia, J.-M.; Brenner, S.E. WebLogo: A sequence logo generator. Genome Res. 2004, 14, 1188-1190. [CrossRef] [PubMed]

61. Schrödinger LLC. The PyMOL Molecular Graphics System; Version 2.4; Schrödinger, LLC: New York, NY, USA.

62. Gawronski, J.D.; Benson, D.R. Microtiter assay for glutamine synthetase biosynthetic activity using inorganic phosphate detection. Anal. Biochem. 2004, 327, 114-118. [CrossRef] [PubMed]

63. Blecher, M.; Glassman, A.B. Determination of glucose in the presence of sucrose using glucose oxidase; effect of pH on absorption spectrum of oxidized o-dianisidine. Anal. Biochem. 1962, 3, 343-352. [CrossRef]

64. Chang, A.; Jeske, L.; Ulbrich, S.; Hofmann, J.; Koblitz, J.; Schomburg, I.; Neumann-Schaal, M.; Jahn, D.; Schomburg, D. BRENDA, the ELIXIR core data resource in 2021: New developments and updates. Nucleic Acids Res. 2021, 49, D498-D508. [CrossRef] [PubMed]

65. Fierobe, H.-P.; Clarke, A.J.; Tull, D.; Svensson, B. Enzymatic Properties of the Cysteinesulfinic Acid Derivative of the Catalytic-Base Mutant Glu400 $\rightarrow$ Cys of Glucoamylase from Aspergillus awamori. Biochemistry 1998, 37, 3753-3759. [CrossRef] [PubMed]

66. Suzuki, Y.; Ueda, Y.; Nakamura, N.; Abe, S. Hydrolysis of low molecular weight isomaltosaccharides by a p-nitrophenyl- $\alpha$-Dglucopyranoside-hydrolyzing $\alpha$-glucosidase from a thermophile, Bacillus thermoglucosidius KP 1006. Biochim. Biophys. Acta Enzymol. 1979, 566, 62-66. [CrossRef]

67. Suzuki, Y.; Uchida, K. Three forms of $\alpha$-glucosidase from welsh onion. Agric. Biol. Chem. 1984, 48, 1343-1345. [CrossRef]

68. Wongchawalit, J.; Yamamoto, T.; Nakai, H.; Kim, Y.-M.; Sato, N.; Nishimoto, M.; Okuyama, M.; Mori, H.; Saji, O.; Chanchao, C.; et al. Purification and Characterization of $\alpha$-Glucosidase I from Japanese Honeybee (Apis cerana japonica) and Molecular Cloning of Its cDNA. Biosci. Biotechnol. Biochem. 2006, 70, 2889-2898. [CrossRef]

69. Kimura, A.; Takewaki, S.; Matsui, H.; Kubota, M.; Chiba, S. Allosteric properties, substrate specificity, and subsite affinities of honeybee $\alpha$-glucosidase, I. J. Biochem. 1990, 107, 762-768. [CrossRef]

70. Kato, N.; Suyama, S.; Shirokane, M.; Kato, M.; Kobayashi, T.; Tsukagoshi, N. Novel $\alpha$-glucosidase from Aspergillus nidulans with strong transglycosylation activity. Appl. Environ. Microbiol. 2002, 68, 1250-1256. [CrossRef]

71. Kita, A.; Matsui, H.; Somoto, A.; Kimura, A.; Takata, M.; Chiba, S. Substrate specificity and subsite affinities of crystalline $\alpha$-glucosidase from Aspergillus niger. Agric. Biol. Chem. 2014, 55, 2327-2335. [CrossRef]

72. Kim, N.R.; Jeong, D.W.; Ko, D.S.; Shim, J.H. Characterization of novel thermophilic alpha-glucosidase from Bifidobacterium longum. Int. J. Biol. Macromol. 2017, 99, 594-599. [CrossRef]

73. Bravo-Torres, J.C.; Villagómez-Castro, J.C.; Calvo-Méndez, C.; Flores-Carreón, A.; López-Romero, E. Purification and biochemical characterisation of a membrane-bound $\alpha$-glucosidase from the parasite Entamoeba histolytica. Int. J. Parasitol. 2004, 34, 455-462. [CrossRef] [PubMed]

74. Giudicelli, J.; Emiliozzi, R.; Vannier, C.; De Burlet, G.; Sudaka, P. Purification by affinity chromatography and characterization of a neutral $\alpha$-glucosidase from horse kidney. Biochim. Biophys. Acta Enzymol. 1980, 612, 85-96. [CrossRef]

75. Tanaka, Y.; Aki, T.; Hidaka, Y.; Furuya, Y.; Kawamoto, S.; Shigeta, S.; Ono, K.; Suzuki, O. Purification and characterization of a novel fungal $\alpha$-glucosidase from mortierella alliacea with high starch-hydrolytic activity. Biosci. Biotechnol. Biochem. 2002, 66, 2415-2423. [CrossRef] [PubMed]

76. Yamasaki, Y.; Miyake, T.; Suzuki, Y. Properties of crystalline $\alpha$-glucosidase from mucor javanicus. Agric. Biol. Chem. 1973, 37, 251-259. [CrossRef]

77. Matsui, H.; Ito, H.; Chiba, S. Low Molecular-Activity $\alpha$-glucosidase from ungerminated rice seed. Agric. Biol. Chem. 1988, 52, 1859-1860. [CrossRef]

78. Yamasaki, Y.; Fujimoto, M.; Kariya, J.; Konno, H. Purification and characterization of an $\alpha$-glucosidase from germinating millet seeds. Phytochemistry 2005, 66, 851-857. [CrossRef]

79. Kobayashi, I.; Tokuda, M.; Hashimoto, H.; Konda, T.; Nakano, H.; Kitahata, S. Purification and characterization of a new type of $\alpha$-glucosidase from paecilomyces lilacinus that has transglucosylation activity to produce $\alpha-1,3-$ and $\alpha-1,2-$ linked ... . Biosci. Biotechnol. Biochem. 2003, 67, 29-35. [CrossRef] [PubMed]

80. Okuyama, M.; Tanimoto, Y.; Ito, T.; Anzai, A.; Mori, H.; Kimura, A.; Matsui, H.; Chiba, S. Purification and characterization of the hyper-glycosylated extracellular $\alpha$-glucosidase from Schizosaccharomyces pombe. Enzyme Microb. Technol. 2005, 37, 472-480. [CrossRef]

81. Choi, K.-H.; Hwang, S.; Cha, J. Identification and characterization of malA in the maltose/maltodextrin operon of Sulfolobus acidocaldarius DSM639. J. Bacteriol. 2013, 195, 1789-1799. [CrossRef]

82. Sørensen, S.H.; Norén, O.; Sjöström, H.; Danielsen, E.M. Amphiphilic Pig Intestinal Microvillus Maltase/Glucoamylase. Eur. J. Biochem. 1982, 126, 559-568. [CrossRef]

83. Seo, S.H.; Choi, K.H.; Hwang, S.; Kim, J.; Park, C.S.; Rho, J.R.; Cha, J. Characterization of the catalytic and kinetic properties of a thermostable Thermoplasma acidophilum $\alpha$-glucosidase and its transglucosylation reaction with arbutin. J. Mol. Catal. B Enzym. 2011, 72, 305-312. [CrossRef]

84. Alarico, S.; Da Costa, M.S.; Empadinhas, N. Molecular and physiological role of the trehalose-hydrolyzing $\alpha$-glucosidase from Thermus thermophilus HB27. J. Bacteriol. 2008, 190, 2298-2305. [CrossRef] 
85. Matsui, H.; Yazawa, I.; Chiba, S. Purification and substrate specificity of sweet corn $\alpha$-glucosidase. Agric. Biol. Chem. 1981, 45, 887-894. [CrossRef]

86. Saburi, W.; Mori, H.; Saito, S.; Okuyama, M.; Kimura, A. Structural elements in dextran glucosidase responsible for high specificity to long chain substrate. Biochim. Biophys. Acta Proteins Proteom. 2006, 1764, 688-698. [CrossRef]

87. Kurakata, Y.; Uechi, A.; Yoshida, H.; Kamitori, S.; Sakano, Y.; Nishikawa, A.; Tonozuka, T. Structural Insights into the Substrate Specificity and Function of Escherichia coli K12 YgjK, a Glucosidase Belonging to the Glycoside Hydrolase Family 63. J. Mol. Biol. 2008, 381, 116-128. [CrossRef] [PubMed]

88. Torres-Rodríguez, B.I.; Flores-Berrout, K.; Villagómez-Castro, J.C.; López-Romero, E. Purification and partial biochemical characterization of a membrane-bound type II-like $\alpha$-glucosidase from the yeast morphotype of Sporothrix schenckii. Antonie Van Leeuwenhoek 2012, 101, 313-322. [CrossRef] [PubMed] 